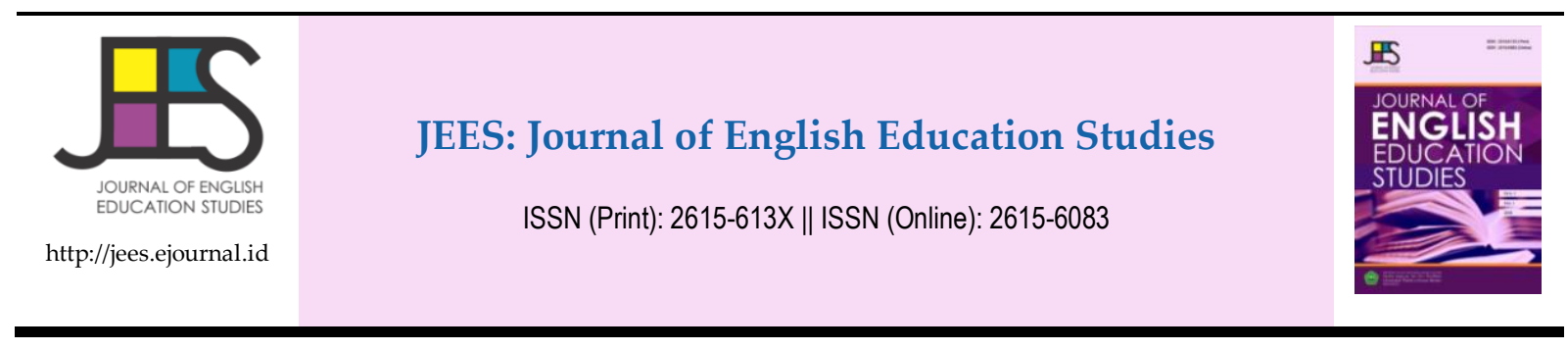

\title{
An Analysis of Students' Listening Comprehension Through Video-Based Internet Material (BBC) in Second Grade Students of SMAN 4 Bandar Lampung in 2016-2017
}

\author{
Yoga Prasetya ${ }^{1}$, Helta Anggia ${ }^{2}$ \\ ${ }^{1}$ Department of English Education, Universitas Bandar Lampung, ${ }^{2}$ Department of English Education, Universitas Bandar Lampung
}

\section{ARTICLE INFO}

Keywords:

BBC, website, listening,

\begin{abstract}
This research aims to apply BBC (British Broadcasting Cooperation) to students. BBC is one of broadcaster in Britain and it provides a website to learn. Its name is BBC Learning English and it shows many videos and the facilities to learn. The purpose of this research is to analyze the students' listening comprehension. In this research, I used qualitative research. The kind of research was used to get information about phenomenon and an accident during the research. The method of this research was audio-visual method where students used their sight and hearing sense. Because BBC provided many videos, it was apt with this method. In here, students did not merely acquire the information from their hearing sense but they were helped by the picture and the accident. The result of this research showed that the improvement from first meeting to second meeting. The improvement happened in their comprehension. In the first meeting, six students can be said fail in the test. They wrote everything in the video but they could not comprehend the topic. In the second meeting, most of them caught the material well. The topic was comprehended extensively. Mostly, students could simply comprehend the material that I presented through BBC. Based on the fact in this research, they preferred to use this website than others. It stimulated them to learn. It is a proof that BBC could help them in the listening comprehension. It is not only about listening comprehension but students could learn grammar and vocabulary.
\end{abstract}

This is an open access article distributed under the terms of the Creative Commons Attribution 4.0 International License, which permits unrestricted use, distribution, and reproduction in any medium, provided the original work is properly cited. @ 2019 Yoga Prasetya, Helta Anggia

\section{INTRODUCTION}

There are so many outlaying places in some districts in Indonesia. They get less attention of education so that it is very difficult to get good education in there. Moreover learning English cannot be said optimal for the reason that English status is as a foreign language. English as part of subject to be learned in Indonesian curriculum is seen as something that is not important. English learning looks like something strange so English cannot be said optimal.

${ }^{1}$ Corresponding author's address: Department of English Education, Universitas Bandar Lampung, Bandar Lampung, Indonesia e-mail: yprasetya733@gmail.com

${ }^{2}$ Corresponding author's address: Department of English Education, Universitas Bandar Lampung, Bandar Lampung, Indonesia e-mail: helta@ubl.ac.id 
English as a foreign language is only learned at school. When students are in the society, they talk to others using Indonesian. Mostly Indonesian people speak using their local language in their daily conversation. This phenomenon support the condition that students are not accustomed to use English. The future teacher especially should be able to manage the existing media in contemporary times. Moreover, the rapid technological development forces the educational system to adapt with technology thus, this condition urges the teachers to provide more attractive learning environment (Sidabalok and Fitirana, 2018). Gagne (1970) as cited in Sadiman (2006:6) explains that media is different types of components in the environment that can stimulate students to learn. Teachers should be able to utilize the media from the internet and they could increase students' motivation to learn. The students' spirit can change their behavior to learn.

To achieve the learning objective, teachers are demanded to convey the material with effective way because some students still think that study is enough in the school. Anggia and Ginola (2016) Stated choosing materials is the highest thing that should be considered for a teacher before delivering the materials because it refers to students' motivation in learning. There are many sources material that you can find in the world. It can be from the book from government, the internet or many kinds of media that can be used as the materials as long as the materials are appropriate for the students and can support the learning process.

Many teachers present the lesson material to students based on knowledge that they had but I emphasize that the students have to grab the lesson material from the source. So they grab the material from the real source not only teacher's explanation. Teacher may suggest them an interesting learning source as the effective way in learning. They can learn individually without teacher's attendance.

It will be SCL (student centered learning). This learning gives priority to students to active during the lesson in the class. Active learning is anything that students do in the class other than simply watching, listening, and taking notes (Felder \& Brent, 2009: 2). The students do not depend on the teacher much because the teacher is only a facilitator.

They can do an active activity even though listening, watching, taking notes and other activities can be said a passive activities, teachers should make their class to be interesting and SCL. It means that the students enjoy their activity even though it is passive activity. Teacher can insert other activities related with their lesson and they also can apply something new in the internet.

Previous paragraph tells about SCL. It means the students are more active during teaching learning process. They do not depend on the teacher to obtain the source of the lesson. They can access the internet to obtain it. Many sources which can be used to learn, one of source is BBC.

Based on the fact above, teachers could obtain the other sources. One of the sources that can be applied by teacher is the BBC (British Broadcasting Corporation). BBC is a British public service broadcaster. It is founded by John Reith. This learning source has videos, scripts, reference vocabularies, etc. that can be used in many activities for those four language skills.

Students could learn English from Native Speaker from the videos which are showed. BBC provides some materials through the news video. It can be sport videos, art, culture and BBC learning English.

The students can learn from those sources and they would listen and watch the material from native speaker directly through the video. They could figure out the material easily. 
A lot of researchers often research this method. This method which is researched, it is audio visual method which BBC as the students' source. Students are analyzed, whether they can comprehend its materials or not. It displays a lot of source of lesson and it provides levels of lesson for students. The study applies BBC for listening skill and actually it is for beginner. I would have a research entitled "An analysis of students" listening comprehension through video-based internet material $(\mathrm{BBC})$ ".

\section{LITERATURE REVIEW}

Listening is the most general activity in our daily life. It has a vital role in language acquisition process. We may listen as much as we speak, four times more than read and five times more than write (Morley, J. 1991). It means that we are more likely to listen than do other activities because so many sound that we may listen. Listening comprehension strategies are techniques or activities that contribute directly to comprehension and recall of listening input, according to (Freeman, 2004 \& Lin, 2006) as cited in (Ghoneim, 2013 : 102). The components which are involved in listening comprehension

Speech perception focuses on the sound discrimination, recognize stress patterns, intonation, pauses, etc. It pays attention in the context of sound. Each single person may speak differently (incorrect pronunciation) and produce different sound. It will influence the other person's comprehension. Because some people speak with incorrect pronunciation, we should try to figure out what the speakers' meaning. It means that we should pay attention in the context of sound to avoid a mispronunciation.

Word recognition emphasizes on the word (e.g., recognize the sound pattern as a word, locate the word in the lexicon, retrieve lexical, grammatical and semantic information about the word, etc.). The hearer focuses on the words and his/her mind will analyze about stress and the meaning of each single word or semantically.

Sentence processing (parsing; e.g., detect sentence constituents, building a structure frame, etc.). It means that the sentences that appear, it emphasizes on the structure frame and the listener detects sentence constituents.

Construct the literal meaning of the sentence (select the relevant meaning in case of ambiguous word). The listeners choose the specific meaning without any other meanings from the word (unambiguous). They should know the meaning of single word.

Hold the information in short-term memory. The listeners get information from the source of material and they keep it in their mind temporarily. The information which has been got will be used for the next activity. It can be a summary or question answer session. They think what they have got and they do those activity. They remember the information or not in short-term memory.

Recognize cohesive devices in discourse. The listener or reader should pay attention in cohesive devices. It is like linking words, linkers, and connectors. It gives a signal what the relationship are between the different clauses, sentences, and paragraphs. It helps them to give different signals and change the meaning of the sentence to the reader and listener.

Infer the implied meaning and intention (speech act). The listeners guess what the meaning of whole content. They try to look at the purpose of the material and try to comprehend the meaning. The purpose or the meaning of the whole content can be guessed so the listeners scrutinize what happen in that material. 
Predict what is to be said. The listeners can hear what speaker talks about so they can guess what the next utterance is. The utterance or object that has been predicted by listener, it means the listeners are very concentrate and they follow the topic well. It needs a full of concentration to comprehend the material so they pay attention well.

Decide how to respond. When the listener hears speaker and it will appear discussion between listener and speaker. During discussion, there is an asking question session. The listeners should respond in the good way. In that way, they can deliver their idea or answer.

All of them involve in listening. Listening can be done well if we try to implement those elements. They are keys of listening comprehension. When speaker encodes language, the hearer decodes the context. The hearers focus on what the speaker wants to deliver. Sometimes, the hearers make some errors in listening activity. The errors often happen during the activity. Because they learn English as a foreign language, the first language influences their foreign language. The errors appear because of some reasons. According to Buck, G. (2001) there are some main reasons why the English language learners make listening errors: (1) they do not get used to the linguistic system of English, (2) they are unfamiliar with the socio-cultural context of the message, (3) their knowledge is based on their own background, and (4) their first language influences the English (vocabulary, phonetic system, and cultural nuances). The beginners maybe make some errors like that. When they practice continuously the kind of errors like that will reduce.

Listening practice commonly is too difficult for beginners, if they only listen the mp3. Sometimes, they are not familiar with the conversation quickly. A nice step for beginners is to display the speaker in a video or show images that are being discussed. Precisely, they can use audio-visual learning. They do not only listen from the video but they can see the speaker talks. The body movements, gestures, pictures etc. which are displayed, all of them help beginners to catch the speaker's point. The teachers easily can download the source of videos according to their needs from the internet, many videos which have been prepared for teaching language. The human being learns more easily and faster by audio-visual processes than by verbal explanations alone (Eze,E.U. 2013) as cited in (ashaver \& igyuve, 2013 : 45). It means, the human especially students catch material of lesson by audio-visual easier than students who only read the explanation from the textbook. They can understand much by listening and hearing. It is more difficult, if students read the book and try to figure out the content.

One of website that can be used is BBC (British Broadcasting Corporation). Popularly this website is a British public service broadcaster in London. It is built by John Reith in January $1^{\text {st }} 1992$. There is another website from BBC too. The name of the website is BBC learning English. It was intentionally designed for student learning. The website provides free resources and activities for both teachers and students. BBC also displays the video that will be used for learning and it is completed by transcript and the activity for students. Students also can learn the grammar and vocabulary because BBC contains it. Besides, BBC can also enrich a student's knowledge of news that appears in video. This website is very suitable for learning. It does not only give a lot of benefits but teacher can use existing media to reach the goal. The implementation of BBC is very appropriate to be become the listening material for beginners and English language learner, and the purpose of using BBC and others media is for increase students' motivation in learning.

Motivation is important to students because it influences their motivation to learn. As stated by Anggia and Ginola (2016) using authentic materials can has many advantages for both the teacher and the students. For the teacher, they can improve the way the teacher lead the class and made the material more innovative. For the students, by using authentic materials like BBC, the students will increase their interest and motivation in learning. It becomes a key factor to a success in 
students learning. Most researchers said that the students learn using the aid of video as their media. They fell more comfortable than they must pay attention to teacher's explanation. In that case, students have a predilection to learn from the website. Teacher should be able to raise students' motivation in learning. High motivation is needed for students. It is the stimulation for students to learn. The problem which is faced for government is the children do not have penchant in learning. One of reason is they were bored when they were reading many books. Teacher can shift the kind of problems into the other path. Students' motivation is decrease when they were reading books. Teacher can implement the $\mathrm{BBC}$ as another way to reduce the problem.

Besides, they can be active in the class, it will give many benefit for both teacher and students. On the other hand, high motivation can make up for considerable deficiencies both in one's language aptitude and learning conditions (Dörney, 1998: 117). Even though the students do not have knowledge much about language, their motivation can cover up their weakness. The motivation can bring a success because the motivation of people can bring them constantly do their job and loves their job.

\section{METHODOLOGY}

This research is a qualitative research. I used the method of audio visual to implement students' listening comprehension in BBC website. Students got explanation from the video. After watched the video, students were required to complete a written test, discussion and interview. The test proved whether the students were able to comprehend the material or not. From this, we could see the use of BBC influences their motivation or not.

The number of student was not too many because this is the experimentation for beginners. The experimentation was done in two meetings to see their improvement in listening subject. BBC learning English as the listening material would be applied in this research.

Qualitative contains the data which we get in order to deliver the occurrence (Creswell, 2012: 18). I will gather the data by giving two kinds of test and interview to students of senior school. Firstly, the students will see and listening the material in the class, and they are given the test and interview related with listening comprehension and BBC. The tests have purpose to analyze their comprehension and the interview is to know their ambition and motivation in this learning. The result of the test will be the data. The data will show that they get improvement in listening comprehension or not. After I know students' comprehension in the listening, I ask them to share about this teaching learning process.

I combined the result of data into paragraph and table. The written test and interview will became the data. The data would be combined with the category of comprehension. It was to analyze whether the students include those categories or not. Those data became a result of this research. I counted the result of data such as the mean of answer. I drawed the mean of the students' answer with the table. So I could see how much students' improvement.

\section{DISCUSSION}

Based on the fact in the first meeting, six of fifteen students give wrong answers in comprehension. In this case, I will discuss the analysis of students' answer with speaker's point. The speaker's point is about the confusion of the woman wears clothes. The woman has two meetings tonight. She wants to work and meet with her friends but she cannot decide the clothes that she wants to wear. She has tried a lot of clothes but she always feels unsuitable with the clothes that she chooses. Finally, the woman chooses a red dress to go tonight. 
Student 1's answer is "The woman who is confuse to adapt the clothes in the night". Student 1 gives that kind of answer because he guesses the answer based on what he gets in the video. He does not take notice in what a speaker says.

"I think that she is suitable with a jeans and jumper to meet her friends" is the student 2's answer. In this case, he has a hunch of the video. Actually before I play the video, I ask them to comprehend the video and tell it in the piece of paper. This student gives an opinion because he does not pay attention in my instruction.

"I think that you are better to wear a jeans and jacket to meet your friend tonight" is student 3's answer. It is precisely the same as student 2's case. The answer is still about opinion and the answer is wrong. Based on the fact, this student assumes that the video is kind of question so she gives her opinion to answer it. This is a same case with student 2 .

The student 4's answer is "the woman who confuses to wear the clothes in compatible time". The answer is less accurate. It is still wrong because he only looks the expression of woman when she decides the clothes. If the students can illustrate in detail, the answer can be correct.

"She is change jas, casual, levis, dress, sweter" is student 5's answer. This student reveals everything that the woman wears. The first mistake is he only watch and write the things and he does not comprehend it by hearing speaker's point. The second mistake that student makes, she writes ungrammatically.

The student six's answer is "She is talk about everyday clothing". The case of this answer specifically is incorrect because this student does not figure out the speaker's point. He also does not focus on why the woman always changes the clothes. She directly takes a conclusion and answer generally.

I analyze their answer with the script that is provided by BBC. Six students answer inaccurately. Even though they produce the answer in general, it does not prove enough to comprehend widely. The more they describe in detail then they really comprehend the topic.

In the second meeting, almost all students answer correctly and specify all points.

"this video tells about Emma jealous

Emma jealous because her friends away on holiday

Emma want to trip with her friends like to see Tajmahal

Emma gift post card from mike, he tells Emma bahwa ia

Ada di Russia. And mike send a photos to Emma"

Text 4.2.1 student's answer

This is one example of their answer. This student can describe every point in the video. It proves that she can comprehend widely even though she writes ungrammatically. Basically, I analyze their comprehension but I correct their grammar also. This is with correct grammar.

“This video tells about Emma's Jealousy

Emma is jealous because her friends always go on holiday

Emma wants to go with her friends, Emma wants to see a Taj mahal 
Mike gives Emma a postcard and he tells that he is In Russia and Mike sends a photo to Emma".

Text 4.2.2 the grammar correction of the student's answer

The text above is about the correction of the grammar and I show you a script in BBC. The script shows a speaker's point and I compare how extent their comprehension.

I'm so jealous. My friends are always going on holiday. Look at all the postcards they've sent me. I wish I was going on a trip somewhere... an exciting adventure to somewhere exotic like the Himalayas or to see the Taj Mahal...

Look: Mike sent me a postcard today. Let's see what it says.

"Hi Emma! Hello from St Petersburg in Russia! Staying in a wonderful hotel. You would love it. The hotel is right by the river. Wish you were here, love Mike."

That sounds wonderful. I do need a holiday but do I want to go there? Hmmm...

\section{The script 4.2.1}

The script above shows what speaker says in the video. There are some points that students write in their answer. Even though they do not write, same as speaker says but they can comprehend the video.

In this case, I want to analyze about the student's answer in text 4.2.2 and the script 4.2.1. I want to look the points that student gives and compare with the script of BBC. In the first point, student answers the main point. "This video tells about Emma's jealousy" is her main point. Second point is about Emma is jealous because her friends always go on holiday. The second point is in the first and second sentence of the script 4.2.1.

The third point is "Emma wants to go with her friends, Emma wants to see a Taj mahal". In this point, student tells about Emma's desirability to go to a Taj Mahal with her friends. This point indicates in the second and third line. Actually, the speaker of BBC does not mention Emma's friends as the people who accompany Emma. The student can comprehend the place that Emma wants to go.

The next point is "Mike gives Emma a postcard and he tells that he is in Russia". This point is in the fourth and the fifth line of the script 4.2.1. "Mike gives Emma a postcard" is a first sentence. "He tells that he is in Russia" is a second sentence. The first sentence has represented the answer in the fourth line. The box shows that Mike is staying in the wonderful hotel and the hotel is right by the river. The student only mentions Russia, she does not explain more about the condition of the hotel.

The last point is "Mike sends a photo to Emma". This is little bit wrong because Mike sends Emma a postcard. In the postcard, there is a picture about the place. It makes this student has a hunch. She assumes that the photo and postcard are same because it is like in one paper. 
The result of questionnaire shows that the students respond in good answer. Actually, I am divided into 5 choices. There are very bad, bad, enough, good and very good answer. Most of them respond good answer except number nine of questionnaire in the result. Number 9 is only five students who respond good answer. Eight students respond enough answer.

I also use interview to strengthen the questionnaire. in the interview, I take five students as participants because it will ascertain their motivation. There are three points or elements that I insert in the interview. There are students' opinion of BBC, students' comprehension and students' motivation/interest.

Those three points are used to know deeper about BBC in the questionnaire. Even though the students only open this website in the school, they prefer use this website than others. The result of interview has been made into transcript. It is in an appendix.

\section{CONCLUSION}

In the result, six students have failed the comprehension test through BBC source. It happens in the first meeting. It is not only comprehension but they do mistake in grammar. They cannot describe more about the video and the rest of students are able to comprehend well.

In the second meeting, most of them can give the answer in the detail even though the big mistake is still in the content of grammar. They are able to mention many points in this meeting so their comprehension is wide. BBC provides the multiple-choice question and I test them by using this kind of question. It aims to strengthen their comprehension.

In this meeting, I do not only test their comprehension but their motivation. The motivation that I apply is extrinsic motivation. It means that whether BBC can motivate them to learn or not. BBC is as a stimulation tool for learning.

Even though they only open it in the school but they prefer using BBC than tape recorder. The other case, when they learn listening skill sometimes their teacher only read the text. The students listen it and try to answer the exercise. This is the fact that I meet. When I apply this website, they like it.

I have some reasons about their comprehension. Their comprehension averagely based on the picture and the accident that appear in the video. They see the picture and the accident and they connect to the story that they make. I find this case from students who only answer from the picture, including student five.

The other reasons are their opinion and misunderstanding of the topic. The opinion appears when students try to answer the topic but they use their opinion to tell the topic. They do not tell based on the accident in the topic. This case is done by student two and three.

Misunderstanding appears when they fail to catch the point and they write the answer based on their understanding. It is done by student six. Even though there are six students fail in the listening comprehension in the first meeting, they get improvement in the second meeting. The process of their comprehension gets better. It can be seen from their result of test.

Based on the first meeting and second meeting, I can conclude that BBC is helpful for teaching learning process. Beside it can make the lesson to be variant, it facilitates them. They can comprehend well with BBC and they get improvement. It is very important to be learned for students at beginner level. 


\section{REFERENCES}

Ashaver, D., \& Igyuve, S.M. (2013). The Use of Audio-VIusal Materials in the Teaching Learning Processes in Colleges of Education in Beneu State-Nigeria. IOSR Journal of Research $\mathcal{E}$ Method in Education (IOSR-JRME)

Anggia H. \& Ginola D. (2016). The Use of Authentic Materials in Speaking Class at The Second Semester Students of English Education Study Program of Teacher Training and Education Faculty of Bandar Lampung University. The Fourth International Conference on Education and Language (4th ICEL)

Buck, G. 2001. Assessing Listening. New York:Cambridge University Press.

Creswell, J.W. (2012). Planing, Conducting, and EvaluatingQuantitative and Qualitative Researh. Boston: Pearson.

Dörnyei, Z. (1998). Motivation in Second and Foreign Language Learning. Language Teaching,

Felder, R.M., \& Brent, R. (2009). Active Learning an Introduction. North Carolina : ASQ Higher Education Brief.

Ghoneim, N.M.M. (2013). The Listening Comprehension Strategies Used by College Students to Cope with the Aural Problems in EFL Classes: An Analytical Study. English Language Teaching,

Morley, J. (1991). The Pronounciation component in Teaching English to Speaker of Other Languages.TESOL QUARTERLY

Sadiman, A. (2006). Media Pendidikan: Pengertian, pengembangan dan pemanfaatannya. Rajawali Pers.

Sidabalok, D.M. and Fitriana, S. (2018). The Analysis of Students' Critical Thinking in Online Discussion Forum by Uisng Schoology in Speaking B Class of First Semester Students of FKIP UBL. Linguistika: Jurnal Pendidikan Bahasa Inggris. Bandar Lampung: Program Studi Pendidikan Bahasa Inggris Fakultas Keguruaan dan Ilmu Pendidikan Univeritas Bandar Lampung 